\title{
Logging and soil nutrients independently explain plant trait expression in tropical forests
}

Sabine Both ${ }^{1 *}$, Terhi Riutta ${ }^{2,3}$, C. E. Timothy Paine ${ }^{4}$, Dafydd M. O. Elias ${ }^{5,6}$, Rudi Chino7 ${ }^{7}$ Annuar Jain ${ }^{8}$, David Johnson ${ }^{9}$, Ully H. Kritzler ${ }^{9}$, Marianne Kuntz ${ }^{1}$, Noreen Majalap-Lee ${ }^{10}$, Nora Mielke ${ }^{1}$, Milenka X. Montoya Pillco ${ }^{1}$, Nicholas J. Ostle ${ }^{5,6}$, Yit A. Teh ${ }^{1}$, Yadvinder Malhi' ${ }^{2}$, David F. R. P. Burslem ${ }^{1}$

${ }^{1}$ Institute of Biological and Environmental Sciences, University of Aberdeen, 23 St Machar Drive, Aberdeen, AB24 3UU, United Kingdom

${ }^{2}$ Environmental Change Institute, School of Geography and the Environment, University of Oxford, South Parks Road, Oxford, OX1 3QY, United Kingdom

${ }^{3}$ Imperial College London, Department of Life Sciences, Silwood Park Campus, Buckhurst Road, Ascot, SL5 7PY, United Kingdom

${ }^{4}$ Biological and Environmental Sciences, University of Stirling, Stirling, FK9 4LA, United Kingdom

${ }^{5}$ Lancaster Environment Centre, Lancaster University, Bailrigg, Lancaster, LA1 4YQ, United Kingdom

${ }^{6}$ Centre for Ecology \& Hydrology, Lancaster Environment Centre, Library Avenue, Bailrigg, Lancaster, LA1 4AP, United Kingdom

${ }^{7}$ Instituto de Ciencias de la Naturaleza, Territorio y Energías Renovables, Pontificia Universidad Católica del Perú, Lima, Perú

${ }^{8}$ The South East Asia Rainforest Research Partnership (SEARRP), Danum Valley Field Centre, PO Box 60282, 91112, Lahad Datu, Sabah, Malaysia

${ }^{9}$ School of Earth and Environmental Sciences, The University of Manchester, Oxford Road, Manchester, M13 9PT, United Kingdom

${ }^{10}$ Forest Research Centre, Peti Surat 1407, 90715 Sandakan, Sabah, Malaysia

*Author for correspondence:

Sabine Both

Tel: +441224274257

Email: sboth@une.edu.au

Current address: Environmental and Rural Science, University of New England, 2351 Armidale,

\section{Australia}

Total word count (excluding summary, references and legends): 4989

Summary: 195

Introduction: 1008

Materials and Methods: 1500 
35 Results: 855

36 Discussion: 1439

37 Acknowledgements: 181

38 No. of Figures: 4

39 No. of Tables: 2

40 No of Supporting Information files: 1 (Fig. S1; Table S1-S4) 
Keywords: anthropogenic disturbance, Borneo, functional diversity, functional traits, land use, Rao's $\mathrm{Q}$, tropical rainforest, variance partitioning
Commented [EDM1]: A suggestion: As reviewer 1 wanted recommendations of previously overlooked traits why not put them here in one sentence as this is an important outcome:

And we recommend inclusion of $\mathrm{x} . .$. traits in future studies 


\section{Introduction}

The differential expression of plant functional traits influences key ecosystem functions (Cornwell et al. 2008; De Deyn et al. 2008; Fortunel et al. 2009; Finegan et al. 2015). Trait expression varies across landscapes due to anthropogenic disturbance, soil characteristics, and other abiotic factors such as climate (Ordoñez et al. 2009; Baraloto et al. 2012; Fortunel et al. 2014a; Dent \& Burslem 2016). Fertile soils are associated with traits conferring rapid nutrient acquisition and use, which support fast growth rates, whereas nutrient-poor soils are often associated with conservative strategies for the maintenance of long-lived tissues (Aerts \& Chapin 2000; Ordoñez et al. 2009; Jager et al. 2015). Anthropogenic disturbances pervade ecosystems worldwide (Hansen et al. 2013) and can affect trait expression in seeds, leaves and woody tissue (Gómez-González et al. 2011; Baraloto et al. 2012; Carreño-Rocabado et al. 2012). Substantial effort has been dedicated to characterising the independent effects of human disturbance (Mclntyre et al. 1999; Mouillot et al. 2013a; Buzzard et al. 2016) and environmental gradients (Fortunel et al. 2014b; Fyllas et al. 2017) on plant trait expression and ecosystem function. However, in practice, communities are influenced by multiple factors simultaneously, and the effects of disturbance may vary along environmental gradients such as nutrient availability.

Comprehensively analysing trait expression in response to multiple gradients is challenging but essential for predicting the ecosystem-level consequences of anthropogenic disturbance. The leaf economics spectrum (Wright et al. 2004; Díaz et al. 2016) suggests that the increase in resource availability associated with disturbance and soil fertility will select for similar leaf trait syndromes. Therefore, functional traits of plant communities should converge at the extremes of environmental gradients. Evidence from tropical tree communities suggests that foliar concentrations of $\mathrm{N}$ and $\mathrm{P}$ and specific leaf area increase in response to gradients of both disturbance (Baraloto et al. 2012; CarreñoRocabado et al. 2012; Carreño-Rocabado et al. 2016) and soil nutrient availability (Fyllas et al. 2009; Fortunel et al. 2014a; Apaza et al. 2015; Jager et al. 2015; Turnbull et al. 2016; Van der Sande et al. 2016). Similarly, leaf dry matter content and branch and stem wood density decrease with both disturbance (Verburg \& van Eijk-Bos 2003; Baraloto et al. 2012; Carreño-Rocabado et al. 2012; Carreño-Rocabado et al. 2016) and soil nutrients (Ordoñez et al. 2009; Fortunel et al. 2014b; Jager et al. 2015). All these studies, however, share twolimitations: they did not examine the influence of multiple factors on trait expression, and they used a restricted set of traits. Moreover, many did not consider traits associated with ecologically important processes, such as structural and defence compounds (important for herbivory and hence trophic interactions); photosynthetic activity (essential for biomass production); and leaf $\delta^{15} \mathrm{~N}$ values (provides insight into sources and use of 
nitrogen). Our understanding about the links between trait sensitivity to anthropogenic disturbance, soil properties, and ecosystem processes in tropical forests therefore remains incomplete.

The consequences of changes in community structure and diversity for ecosystem service provision are determined by the impacts of disturbance on community-level trait expression, which is a function of the type and intensity of disturbance. For example, in South American tropical forests, disturbance due to logging and silvicultural activity increases light availability and triggers the recruitment of species with traits that promote rapid growth rates (Baraloto et al. 2012; CarreñoRocabado et al. 2012). We expect a similar response to logging in Southeast Asian tropical forest. We build upon these studies to additionally determine the influence of soil properties, including nutrient availability on functional traits.

Tropical lowland forests in Southeast Asia are amongst the most species-rich communities worldwide, but are also the most threatened by logging and conversion to agriculture (Hansen et al. 2013; Edwards et al. 2014; Stibig et al. 2014). The high density of commercially valuable species explains the high intensity of logging in Southeast Asian forests (Osman et al. 2012; Gaveau et al. 2014), which suffer rates of extraction that far exceed those in tropical forests elsewhere (see Asner et al. 2005 for the Brazilian Amazon and Rutishauser et al. 2015 for various sites in the Amazon Basin). Logging creates a spatially patchy disturbance, with gaps and skid trails characterised by high light and temperature distributed among fragments of relatively unmodified forest (Johns 1997). The selective removal of target species, logging-induced mortality and recruitment of pioneer species in disturbed areas affects tree species composition and the pools and fluxes of biomass and nutrients (Cannon et al. 1998; Verburg \& van Eijk-Bos 2003; Pfeifer et al. 2016; Riutta et al. 2018). Although the magnitude of anthropogenic disturbance is much greater in forests in Southeast Asia than in South America, they have received far less attention regarding the modification of plant functional traits. Specifically, the potential for intense logging to override the effects of environmental gradients, including soi properties, has not been investigated.

Here, we measured 32 leaf, wood and physiological traits of 284 tropical tree species to capture community level trait expression in response to selective logging across a gradient of soil properties in species-rich tropical rainforest in Sabah, northern Borneo. We consider traits reflecting nutrient status, light capture, photosynthesis, and allocation to structure and defence, to provide a wholeplant perspective and assess many aspects of functional diversity. We tested the hypothesis that functional trait values and functional diversity shift in response to anthropogenic disturbance and soil properties. We used community-weighted mean (CWM) values of traits to quantify average trait values, and a multi-trait index of functional diversity (FD) to quantify trait variation, which can occur independent of variation in CWM trait values (Ricotta \& Moretti 2011). 
Specifically, we predict that (1) increasing disturbance and soil nutrient availability will increase CWM traits related to tissue nutrient concentrations and carbon assimilation rates, but reduce tissue densities and investments in structural defences. Given the high logging intensity in Southeast Asia, we further predict that (2) a greater proportion of the variance in CWM traits will be explained by logging than by soil properties, emphasizing the pervasive impact of anthropogenic land use on functional trait expression. Finally, due to the high overall tree species richness, we predict that (3) functional diversity will remain high in response to disturbance, despite shifts in overall CWM traits.

\section{Material and Methods}

Study sites

Sampling was conducted in eight 1 ha plots in Sabah, Malaysian Borneo. The plots are part of the Global Ecosystems Monitoring (GEM) network of permanent sample plots with intensive, regular carbon cycle measurements (Malhi et al. 2015; Riutta et al. 2018) and were selected to capture variation in logging intensity across a range of lowland tropical forests in northern Borneo. Old-growth lowland mixed dipterocarp forest plots (hereafter OG) were located in the Maliau Basin Conservation Area (MBCA, two plots) and the Danum Valley Conservation Area (DVCA, two plots), while the other four plots were distributed between these two areas in the selectively logged Kalabakan Forest Reserve (hereafter SL). The four logged plots are part of the Stability of Altered Forest Ecosystem (SAFE) project (Ewers et al. 2011). This area has been logged two times with the first round of logging in the mid-1970s and subsequent repeated logging during 1990-2008. Approximately 150-179 $\mathrm{m}^{3} \mathrm{ha}^{-}$ ${ }^{1}$ of timber was removed over this time period (Struebig et al. 2013), bracketing the mean extraction volume across Sabah (152 $\mathrm{m}^{3} \mathrm{ha}^{-1}$, Fisher et al. 2011).

All three areas are part of the Yayasan Sabah Forest Management Area and belong to a formerly connected area of lowland dipterocarp rainforest characterised by high species richness and many tall, emergent trees. The region has a moist tropical climate with an annual daily mean temperature of $26.7{ }^{\circ} \mathrm{C}$ and annual precipitation of approximately $2600-2700 \mathrm{~mm}$ (Walsh \& Newbery 1999). Although the climate is aseasonal there are occasional droughts and dry spells associated with supraannual El Niño Southern Oscillation events (Walsh \& Newbery 1999; Newbery \& Lingenfelder 2009). The forest soils in Sabah are mostly orthic Acrisols or Ultisols (for more details see Marsh \& Greer 1992; Nainar et al. 2015).

\section{Sampling design}

Thirty-two functional traits were measured on 651 individual trees $\geq 10 \mathrm{~cm}$ diameter at breast height (dbh) representing 284 species during an intensive sampling campaign from July to December 2015.
Commented [SB2]: Terhi: based on the Ewers et al RoySoc paper 2011, the sites only have been logged twice. Could the number 2-4 been based on your information? Do you have an opinion what statement to use?

Commented [SB3]: Add geographic distance here - is there any GEM/SAFE general information? 
We combined two strategies to sample the functional trait values in each plot. In the first, weighted basal area strategy, we sampled species that most contributed to the total plot basal area. This approach assumes that species accounting for a larger proportion of plot basal area also make a greater contribution to ecosystem functioning. Species were ranked based on their contribution to total basal area at the most recent census for each plot (2011 to 2015), which ranged from 10.9-41.8 $\mathrm{m}^{2} \mathrm{ha}^{-1}$. All species that contributed to $70 \%$ of plot basal area (in decreasing order of species basal area) were identified for sampling. In $57 \%$ of cases only one individual per species occurred; otherwise, the individual with the greatest dbh within a species was sampled. This strategy disproportionately sampled large-statured and abundant species. To ensure that smaller and potentially rare species were also represented, we adopted a second strategy: stratified random and taxon-independent sampling of all trees $\geq 10 \mathrm{~cm}$ dbh in three randomly selected $20 \times 20 \mathrm{~m}$ subplots within each 1 ha plot. As this strategy allowed for repeated samples of the same species, as well as sampling from all height strata, it contained understory and shaded trees. This combination of different sampling strategies provided a comprehensive representation of the tree community (Paine et al. 2015) and resulted in an overall representation of $>90 \%$ of the total basal area per plot (except one plot with 65\%) and 51$71 \%$ of the species $\geq 10 \mathrm{~cm}$ dbh (Fig. S1).

\section{Soil properties}

We measured total nutrients and exchangeable nutrient pools to estimate both long-term nutrient supply as well as plant-available forms. Two randomly located soil cores were taken per plot in 20142015. Surface soil $(0-10 \mathrm{~cm})$ was analysed for $\mathrm{pH}$, cation exchange capacity and total concentrations of P, C, N, Mg, K and Ca using the protocols of Quesada et al. $(2010,2012)$. To assess availability of K, $\mathrm{Ca}, \mathrm{Mg}, \mathrm{P}, \mathrm{NO}_{3}{ }^{-}$and $\mathrm{NH}_{4}{ }^{+}$we measured nutrient supply rates using in-situ ion exchange membranes (PRSTM Probes, Western AG, Saskatoon, Canada). To account for spatial variability we installed four probe pairs (each composed of one cation and anion probe) vertically at corners of three $50 \times 50 \mathrm{~cm}$ quadrats to $10 \mathrm{~cm}$ depth within each of the three subplots used in the stratified random sampling. These were collected after two weeks, washed with distilled water and sent to the manufacturer for analysis. They pooled the four probe pairs from each quadrat prior to elution with $0.5 \mathrm{M} \mathrm{HCl}$ for $1 \mathrm{hr}$, yielding 72 samples. $\mathrm{NO}_{3}{ }^{-}$and $\mathrm{NH}_{4}{ }^{+}$were measured colorimetrically using automated flow injection analysis (FIA). All other elements were analysed using Inductively Coupled Plasma Mass Spectrometry (ICP-MS). Results are reported as supply rates over the burial period (micrograms $/ 10 \mathrm{~cm}^{2} / 14$ days). 


\section{Trait measurements}

From each target tree, we attempted to sample a fully sunlit canopy branch and a fully shaded branch; however, branches of only one type were available for most trees (91\%) because it was uncommon for large canopy trees to possess fully shaded branches and for small understorey trees to have fully sunlit branches. Branch samples were collected by tree climbing or by cutting from the ground with telescopic branch cutters. Target tree height ranged from 2.3 to $78.1 \mathrm{~m}$, and sample height ranged from $2.3 \mathrm{~m}$ to $53 \mathrm{~m}$. Branches were approximately $2-4 \mathrm{~cm}$ in diameter and provided sufficient leaf material for all analyses. Photosynthetic activity was only measured on trees selected by the basal area sampling strategy due to time constraints $(N=298)$, whereas all other functional traits were determined on all trees. Undamaged mature leaves were collected and cleaned with water for subsequent analyses. Fresh and dry leaf weight, (specific) leaf area, leaf thickness, leaf dry matter content (LDMC), (specific) force to punch and branch wood density were determined in a field laboratory. Dried bulked and milled leaf material was used for determination of $\mathrm{Ca}, \mathrm{K}, \mathrm{Mg}, \mathrm{P}, \mathrm{C}$ and $\mathrm{N}$ concentrations, $\delta^{13} \mathrm{C}$ and $\delta^{15} \mathrm{~N}$ stable isotope composition, cellulose, hemicellulose and lignin concentrations. Analyses of pigments (chlorophyll a, chlorophyll b, and carotenoids), phenols and tannins were conducted on $0.7 \mathrm{~cm}$ diameter leaf discs punched from fresh leaves immediately after field collection and frozen in liquid nitrogen. Herbarium voucher specimens were taken for identification of trees and were deposited in the herbarium at Danum Valley Field Centre. All trait measurements follow standardised protocols (Pérez-Harguindeguy et al. 2013), and detailed methods and an overview of sampling and replication are provided in Table S1.

\section{Statistical analyses}

Replicated leaf-level functional traits were averaged for sun and shade leaves for the few individuals that possessed both to generate a tree-level dataset. Our results were not significantly different for analyses on sun leaves alone, where available, or otherwise shade leaves, so we combined data from sun and shade leaves together. Leaf chemical properties that are most relevant for photosynthetic activity (chlorophyll a, chlorophyll b, bulk carotenoids, $\mathrm{N}$, and P) were expressed as mass-based as well as area-based values. For $43 \%$ of species, multiple individuals were measured and trait values were averaged to result in species-level values. For all analyses, if necessary, species-level leaf traits were log-transformed to improve the normality of residuals. A CWM was calculated for each trait, weighted by the number of individuals of each species in each plot (Pla et al. 2012). Values of dark respiration fluxes and $\delta^{13} \mathrm{C}$ were converted to positive values for ease of interpretation. To characterise soil properties in relation to land use, we performed a principal component analysis (PCA) of soil chemical 
properties across the eight plots with the measurements of total concentrations of $\mathrm{P}, \mathrm{C}, \mathrm{N}, \mathrm{Mg}, \mathrm{K}, \mathrm{Ca}$, exchangeable $\mathrm{Mg}, \mathrm{K}, \mathrm{Ca}, \mathrm{NH}_{4}{ }^{+}$and $\mathrm{NO}_{3}{ }^{-}$, extractable $\mathrm{P}, \mathrm{pH}$ and cation exchange capacity (CEC). To visualise the distribution of CWM traits across forest types and test hypothesis 1 , we conducted a PCA using centred and standardised CWM trait values for each study plot.

In order to test hypothesis 2, site scores from the first two PCA axes of soil properties, along with a binary variable representing logging history, were used as predictors in linear models to partition the variance in each CWM trait. The first two principal components from the soil PCA were both statistically independent of logging history (linear model: $p \geq 0.48$ ). Nevertheless, because the three predictors were weakly but non-significantly inter-correlated $\left(R^{2} \leq 0.29\right)$, we used the hierarchical partitioning method of Chevan and Sutherland (1991), as implemented in the hier.part library of R, to estimate the variance in functional traits explained by each. This technique calculates the $R^{2}$ of every possible model, then averages over this set of models to allocate the variance explained by each predictor variable. It thereby overcomes the effect of the order that inter-correlated variables enter a model on the inference of variance explained by each variable (Chevan \& Sutherland 1991). Tests of significance are less important than partitioning the variance in CWM trait values in this analysis. Nevertheless, given that this analysis generated 99 p-values ( 3 tests on each of 32 functional traits, plus functional diversity), we corrected the p-values using the false discovery rate (García 2004).

To address hypothesis 3, we computed plot-level values of functional diversity (FD) as Rao's quadratic entropy (Rao's Q), which is the sum of the pairwise distances between species in multidimensional trait space weighted by their relative abundance (Rao 1982). It is the functional equivalent of Simpson's diversity index. We compared Rao's Q among forest types with ANOVA.All analyses were performed using R 3.4.0 (R Core Team 2017).

\section{Results}

Forest structure, species composition and soil properties of plots

The study plots varied substantially in basal area (BA) and stem density, with BA varying fourfold (10.9 $\mathrm{m}-41.8 \mathrm{~m}^{2} \mathrm{ha}^{-1}$, Table 1). Basal area was significantly lower in the SL plots but the range among plots within each forest type was similar (means: SL $17.8 \pm 12.7$, OG $34.8 \pm 14.9 \mathrm{~m}^{2}$ ha $^{-1}$; ANOVA: $F_{1,6}=15.26$, $p=0.008)$. Stem density ranged from 331 to $565 \mathrm{ha}^{-1}$, peaking in plots with intermediate BA but was not associated with logging $\left(F_{1,6}=0.02, p=0.90\right)$. Species richness was similar in OG and SL plots, ranging from 124 to 211 tree species ha ${ }^{-1}\left(F_{1,6}=0.55, p=0.49\right)$.

A PCA of soil chemical properties explained $69.5 \%$ on the first two principal axes (Fig. 1). The strongest gradient was defined by variation in total $\mathrm{Mg}$, total $\mathrm{P}$ and $\mathrm{CEC}$, whereas the second axis represented a gradient of total $\mathrm{C}$, total $\mathrm{N}$ and exchangeable $\mathrm{Ca}$ to exchangeable $\mathrm{K}$ and $\mathrm{NH}_{4}{ }^{+}$. Nutrient 
concentrations varied markedly among plots, including 10 -fold and 5-fold variation in total $\mathrm{Mg}$ and total $\mathrm{P}$ concentrations, and 9-fold and 10-fold variation in exchangeable $\mathrm{K}$ and $\mathrm{NH}_{4}^{+}$(Table 1). Soil properties differed among plots, but were independent of logging history, indicated by the overlapping distribution of OG and SL plots in the PCA (Fig. 1).

\section{Community-weighted mean traits}

Major gradients in CWM trait expression were visualised by PCA, with the first two axes explaining $77.7 \%$ of the variance in functional traits (Fig. 2). There was a clear differentiation of functional composition between OG and SL plots along the first principal component, indicated by a distinct clustering of the study plots. Tree communities in OG plots were characterised by greater investment in defence and tissue density, whereas SL tree communities expressed higher photosynthetic activity and reduced investment into structural components (Table 2). Old-growth forests were characterized by denser wood and tougher leaves. These traits reflect enhanced structural investment, implying longer leaf life span and slower growth rates. Tree communities in SL forest had higher photosynthetic activity represented by higher CWM values of $A_{\max }$ and $A_{\text {sat }}$, and higher $R_{d}$. These higher rates of gas exchange were supported by the expression of higher CWM areabased pigment concentrations in SL communities and higher $\mathrm{N}_{a}, \mathrm{~N}_{m}$ and $\mathrm{P}_{\mathrm{a}}$ concentrations. Tree communities in SL were enriched in ${ }^{13} \mathrm{C}$ compared to $\mathrm{OG}$ communities, indicating greater water-use efficiency.

The second axis of functional trait space represented tissue nutrient concentrations and leaf area but was independent of logging history (Fig. 2). This axis reflects covariance among CWM values of leaf area, leaf $\mathrm{P}_{m}, \mathrm{~N}_{m}, \mathrm{Mg}_{m}$ and $\mathrm{Ca}_{m}$ concentrations, and a negative association of these traits with leaf $C_{m}$ and tannin concentrations. Variability of these traits within both logged and unlogged forests was high, which suggests that the expression of these traits is driven by underlying soil properties rather than logging history.

\section{Variance partitioning}

Partitioning the CWM response of traits to logging and the first two principal components of soil properties showed that these factors explained up to $90 \%$ of the variation in traits. Overall, the proportion of variance explained was on average $74.4 \%$. (Fig. 3, Table S4). To present these results, , we group the functional traits based on their main association with leaf nutrients, photosynthesis or structure. Variation in mass-based concentrations of leaf $\mathrm{Ca}_{m}, \mathrm{P}_{m}, \mathrm{~N}_{\mathrm{m}}$ and $\mathrm{K}_{\mathrm{m}}$ and to a lesser extent $\mathrm{Mg}_{\mathrm{m}}$ were associated with variation in soil properties, both with soil PC1 and 2. Particularly soil PC1, enveloping a gradient from exchangeable $\mathrm{Mg}$ to cation exchange capacity (CEC) and total $\mathrm{P}$, strongly affected the variance in leaf $\mathrm{Ca}_{m}, \mathrm{P}_{\mathrm{m}}, \mathrm{C}_{\mathrm{m}}$. However, expressed on area basis, foliar $\mathrm{P}_{a}$ and $\mathrm{N}_{a}$
Commented [cetp4]: I deleted this text because the variation occurs between plots, not only inside the PCA, I think. 
concentrations were mainly explained by logging. Variation in SLA and leaf thickness appears to underlie the contrasting response of mass and area based traits. For leaf traits related to photosynthesis, $33.5-78.6 \%$ of variance was explained by logging and a much smaller proportion by soil PC1 (1.5-21.8\%) or soil PC2 (0.9-35.6\%; Table S4). Structural traits were explained by a combination of both logging history and the independent effects of soil properties. Logging explained on average $39.2 \%$ of variance in traits reflecting tissue density and structural investment, such as specific force to punch and branch wood density, which had consistently lower values in logged forest plots. Community-weighted mean LDMC was unusual in that it was poorly explained by the predictor variables. In contrast, leaf size, expressed as CWM leaf area and leaf mass, incr eased with increasing values of soil PC1, which was linked to plots with higher total $\mathrm{N}$ and exchangeable Ca concentrations (Fig. 1). There was an increase in CWM tannin concentrations in logged forest plots and at higher values of soil PC1. The CWM values of $C_{m}$ and $N_{a}$ were significantly explained by the first principal component of soil properties, and forest type, respectively, whereas other traits were statistically independent of the predictors (Fig. 3)

\section{Functional diversity}

Functional diversity, expressed as Rao's $Q$, was similar between forest types (Fig. 4; $F_{1,6}=0.16, p=$ 0.70), and neither logging nor soil properties explained a significant proportion of its variance (Fig. 3). The main proportion of variance was explained by soil PC2. The negative relationship with soil PC2 indicates xxx. Variability in FD was greater among SL than OG forests (Fig. 4), potentially indicating the heterogeneous conditions resulting from logging.

\section{Discussion}

Logging profoundly affected the expression of plant functional traits in Bornean tropical forests. Logging was the primary driver of variation in community-weighted mean (CWM) values of functional traits (Fig. 2), and explained more variation than soil properties for 20 of 32 traits (Fig. 3). Similar impacts of logging on functional trait expression have been demonstrated in Neotropical forests (Baraloto et al. 2012; Carreño-Rocabado et al. 2012), although those studies did not analyse soilrelated factors. Together, these studies confirm that CWM traits are highly sensitive to land-use change in tropical forests, but results from our study additionally highlight the considerable relevance of the environmental context for trait expression. This is an important outcome in the light of the fact that logging has impacted over half of all tropical forests globally, and over $70 \%$ of forests in Sabah (Bryan et al. 2013; Potapov et al. 2017). Therefore, the effect of logging on the expression of functional traits is likely to pervade tropical forest landscapes and impact ecosystem processes with cascading 
effects on other trophic levels. Moreover, logging-associated changes in forest structure and CWM traits drive altered patterns of productivity in tropical forests (Pfeifer et al. 2016; Riutta et al. 2018).

In our study, the principal axis of functional trait space defined a clear gradient from values of traits that maximise carbon capture and growth, which were predominantly expressed in selectively logged forests, to greater allocation to tissue persistence and stability, which were predominantly expressed in old-growth forests. This strong signal of anthropogenic disturbance is partly congruent with the leaf economics spectrum, which differentiates species along a gradient based on leaf traits contributing to resource acquisition and conservation (Wright et al. 2004; Díaz et al. 2016). Thus, species in logged forest communities expressed higher CWM values of area-based measures of N, P and pigments, whereas old-growth forest communities expressed low CWM values of these traits and higher values of traits conferring structural stability and resistance to herbivory, such as branch wood density and leaf toughness. Supporting hypothesis 1, disturbance enhanced the occurrence of species possessing traits that confer rapid carbon capture and investment in fast growth rates (Baraloto et al. 2012; Carreño-Rocabado et al. 2012, 2016). We add to previous results by additionally demonstrating that logged forest communities expressed higher CWM values of $A_{\text {sat, }}, A_{\text {max }}$ and $R_{d}$, whereas old-growth forest communities were characterised by higher values of traits conferring structural stability of wood and leaves.

We observed lower CWM values of specific leaf area (SLA) in logged forests, in contrast to results from French Guiana (Baraloto et al. 2012), and contrary to the expectation that SLA scales positively with $\mathrm{A}_{\max }$, foliar $\mathrm{N}_{\mathrm{a}}$, and foliar $\mathrm{P}_{\mathrm{a}}$ concentrations among species (Wright et al. 2004). The lack of association between SLA and other leaf-economic traits may be explained by the abundance of pioneer species, which recruit following disturbance and are adapted to resist the more exposed and potentially desiccating conditions created by logging (Hardwick et al. 2015). A reduction in SLA may contribute to photosynthetic water-use efficiency, especially when combined with enhanced investment in photosynthetic enzymes, to ensure draw-down of internal $\mathrm{CO}_{2}$ concentrations at a given stomatal conductance (Reich et al. 2003). Greater enrichment of CWM $\delta^{13} \mathrm{C}$ of logged forest tree communities demonstrates reduced discrimination for the heavier ${ }^{13} \mathrm{C}$ isotope and provides independent evidence of enhanced, integrated water-use efficiency for trees in this hotter and drier environment (Farquhar et al. 1989; Rumman et al. 2018). The absence of a shift in SLA in response to logging in French Guianan forests (Baraloto et al. 2012) suggests that logging imposes a more extreme environmental contrast for trees occurring in the less seasonal climate of Borneo. Species that have evolved in a seasonal climate such as in French Guiana, may be better adapted to changes in microclimatic conditions, like those driven by logging (Blonder et al., unpublished data). The impact of logging may be more severe in tree communities not adapted to drought and emphasises the potential 
sensitivity of Bornean forests to future climatic change. Mean temperature for Borneo is predicted to rise by $0.9-3.2^{\circ} \mathrm{C}$, annual precipitation is predicted to become increasingly drier in central to western Borneo and wetter in northern and north-western Borneo (ICCP 2013; Scriven et al. 2015).

We show that trait expression responded independently to logging disturbance and soil properties. Variation in soil properties can be attributed to interactions between underlying soil texture and mineralogy, on one hand, and the impacts of logging disturbances including soil inversion, removal, and compaction on the other (Pinard et al. 2000). However, soil properties did not differ systematically between old-growth and selectively logged forests (Fig. 1), owing to variation in underlying soil types and the heterogeneous nature of logging. This allowed us to assess their independent effects on the expression of CWM functional traits. For most of the mass-based nutrient concentrations, variation in soil properties explained more variation in CWM trait values than did logging, whereas traits linked to photosynthesis and carbon capture were more sensitive to logging than to variation in soil properties (Fig. 3). The mechanisms underlying these associations deserve further study. An obvious field of research should be the study of post-logging alterations in the fungal community, in particular the occurrence and diversity of ectomycorrhizal fungi (McGuire et al. 2015). They are almost exclusively associated with tree species of the family Dipterocarpaceae, which are also the main family logged for timber (but see Essene et al. 2017). The interacting effects between tree species dominance, logging and below-ground microbial diversity and ecosystem functions are largely unknown.

Moreover, we provide clear evidence that soil properties act on trait expression in two independent ways; the first axis reflected total pools of nutrients, and the second reflected nutrient availability (Fig. 1). Community-weighted mean values of leaf area, leaf dry mass and foliar concentrations of $\mathrm{P}_{m}, \mathrm{P}_{\mathrm{a}}, \mathrm{N}_{\mathrm{m}}$ and $\mathrm{Ca}_{\mathrm{m}}$ all increased in response to the first axis of variation in soil properties, whereas leaf $C_{m}$ and tannin concentrations decreased along this gradient (Fig. 3). The second component of soil variation also influenced some leaf traits, particularly $\delta^{13} \mathrm{C}, \mathrm{N}_{\mathrm{a}}$ and $\mathrm{P}_{\mathrm{a}}$ concentrations (Table 2, Table S4). Moreover, most traits were influenced either by the first or second axis of variation in soil properties, but rarely both. This finding may reflect a trade-off in how plants interact with local edaphic conditions, as suggested in other systems (Laliberte et al. 2015); a key future challenge will be to disentangle the mechanisms underpinning these contrasting responses of functional traits to the soil environment. Our results highlight the need to consider the context dependency of drivers of variation in functional traits. Landscape-level predictions of change in functional trait expression in response to anthropogenic disturbance will need to account for the additional effects of soil properties.
Commented [cetp5]: Add a mention of implications of your results for dynamic global vegetation models here? 
Despite the large variation in CWM traits, functional diversity (FD) did not differ between logged and old-growth forest, which is consistent with our third hypothesis and with results from Neotropical forests (Fig. 4; Baraloto et al. 2012; Carreño-Rocabado et al. 2012). This finding emphasises that forests can retain species richness and trait variation, yielding similar FD, despite logging. In line with Mayfield et al. (2010), logging did not result in loss of FD but in shifts of numerous CWM trait values, indicating a lower sensitivity of multi-trait FD to these changes (Ricotta \& Moretti 2011). FD was more variable among logged forests than old-growth forests (Fig. 4), probably owing to variation in logging history and intensity, which affect forest structure (Cannon et al. 1994; Berry et al. 2008), microclimatic conditions (Hardwick et al. 2015) and ecosystem functions (Mayfield et al. 2006; Both et al. 2017; Riutta et al. 2018). The substantial variance in FD among the disturbed plots highlights the challenge of predicting the impacts of anthropogenic modification on FD in environments where the outcomes may be highly context-dependent (Costantini et al. 2016).

Assessments of functional composition and diversity at a community scale are critical as humanmodified landscapes become more extensive and play an increasing role in the provision of ecosystem services (Berry et al. 2010; Gibson et al. 2011). However, uncertainty remains over how changes in community trait expression will affect ecosystem functioning and resilience after selective logging and other forms of disturbance (Laliberté et al. 2010; Mayfield et al. 2010; Edwards et al. 2014). Part of that uncertainty arises because rare tree species may contribute substantially to resilience (Mouillot et al. 2013b), but tend to be under-represented in traditional sampling designs adopted for measuring ecosystem functions. Our nested sampling design explicitly resolved this issue by selecting both common and rare species across the full range of size classes. We therefore advocate this approach in future assessments of trait expression at the community scale.

We demonstrate a consistent shift in community-level trait expression in response to logging, reflecting a transition from an old-growth forest dominated by individuals with resource conserving, structurally persistent tissues to logged forests manifesting greater capacity for carbon assimilation and vegetative growth. Strikingly, there was a second, independent, axis of functional trait variation reflecting variation in soil properties (i.e. nutrient availability and chemistry including $\mathrm{pH}$ ), which explained variation in leaf size and mass-based foliar nutrient concentrations. The elucidation of these orthogonal dimensions of plant trait variation was made possible by the measurement of numerous functionally relevant traits and by their consideration at the community level, as well as by the inclusion of rare species. These results provide a basis for predicting how pervasive logging disturbance combines with natural gradients to determine trait expression and ecosystem functioning across human-modified tropical landscapes. 


\section{Acknowledgements}

We acknowledge financial support by the UK Natural Environment Research Council (NE/K016253/1), with additional support through an ERC Advanced Investigator Award to YM (GEM-TRAIT; 321131). We are indebted to the Sabah Biodiversity Council, Yayasan Sabah, the Maliau Basin and Danum Valley Management Committees, the Institute for Tropical Biology and Conservation at the University of Malaysia, Sabah, and the Sabah Forest Research Centre at Sepilok. We thank Glen Reynolds and the South East Asia Rainforest Research Partnership (SEARRP). This study was supported by funding from the Sime Darby Foundation to the Stability of Altered Forest Ecosystems (SAFE) Project. This project would not have been possible without the indispensable support from dozens of research assistants. The support from Laura Kruitbos, Unding Jami, Lisa P. Bentley, Benjamin Blonder, Puikiat Hoo, Palasiah Jotan, Alexander Shenkin and Chun Xing Wong is gratefully acknowledged. We thank Bernadus Bala Ola, Bill McDonald, Alexander Karolus and MinSheng Khoo for species identification. This publication is a contribution from the UK NERC-funded Biodiversity And Land-use Impacts on Tropical Ecosystem Function (BALI) consortium (http://bali.hmtf.info) through its Human Modified Tropical Forests thematic programme.

Author contributions: SB, DB and YM designed the study with input from DJ, NO and YAT. SB, DE, TR, UHK, RC and MMP collected field data, SB, RC, DE, AJ, UHK, MK, NML, NM and MMP conducted laboratory analyses. SB and CETP analysed the data. SB led the writing of the manuscript with contributions from all co-authors. YAT, DB, DJ, YM and NO secured the funding. All authors declare no conflict of interest. 


\section{References}

Aerts, R. \& Chapin III, F.S. (2000). The Mineral Nutrition of Wild Plants Revisited: A Re-evaluation of Processes and Patterns. Advances in Ecological Research, 30, 26-27

Apaza-Quevedo, A., Lippok, D., Hensen, I., Schleuning, M. \& Both, S. (2015). Elevation, Topography, and Edge Effects Drive Functional Composition of Woody Plant Species in Tropical Montane Forests. Biotropica, 47, 449-458

Asner, G.P., Knapp, D.E., Broadbent, E.N., Oliveira, P.J.C., Keller, M. \& Silva, J.N. (2005). Selective Logging in the Brazilian Amazon. Science, 310, 480-482

Baraloto, C., Hérault, B., Paine, C.E.T., Massot, H., Blanc, L., Bonal, D., et al. (2012). Contrasting taxonomic and functional responses of a tropical tree community to selective logging. J. Appl. Ecol., $49,861-870$

Berry, N.J., Phillips, O.L., Ong, R.C. \& Hamer, K.C. (2008). Impacts of selective logging on tree diversity across a rainforest landscape: the importance of spatial scale. Landsc. Ecol., 23, 915-929

Berry, N.J., Phillips, O.L., Lewis, S.L., Hill, J.K., Edwards, D.P., Tawatao, N.B., et al. (2010). The high value of logged tropical forests: Lessons from northern Borneo. Biodivers. Conserv., 19, 985-997

Both, S., Elias, D.M.O., Kritzler, U.H., Ostle, N.J. \& Johnson, D. (2017). Land use not litter quality is a stronger driver of decomposition in hyper-diverse tropical forest. Ecol. Evol., 7, 9307-9318

Bryan, J.E., Shearman, P.L., Asner, G.P., Knapp, D.E., Aoro, G. \& Lokes, B. (2013). Extreme differences in forest degradation in Borneo: comparing practices in Sarawak, Sabah, and Brunei. PloS One, 8(7), p.e69679

Buzzard, V., Hulshof, C.M., Birt, T., Violle, C. \& Enquist, B.J. (2016). Re-growing a tropical dry forest : functional plant trait composition and community assembly during succession. Funct. Ecol., 30, 1006-1013

Cannon, C., Kartawinata, K., Leighton, M. \& Peart David, R. (1994). The structure of lowland rainforest after selective logging in West Kalimantan, Indonesia. For. Ecol. Manage., 67, 49-68

Cannon, C.H., Peart, D.R. \& Leighton, M. (1998). Tree Species Diversity in Commercially Logged Bornean Rainforest. Science, 281, 1366-1368

Carreño-Rocabado, G., Peña-Claros, M., Bongers, F., Alarcón, A., Licona, J.C. \& Poorter, L. (2012). Effects of disturbance intensity on species and functional diversity in a tropical forest. J. Ecol., 100, 1453-1463

Carreño-Rocabado, G., Peña-Claros, M., Bongers, F., Díaz, S., Quétier, F., Chuviña, J., et al. (2016). Landuse intensification effects on functional properties in tropical plant communities. Ecol. Appl., 26, 174-189

Chevan, A. \& Sutherland, M. (1991). Hierarchical Partitioning. Am. Stat., 45, 90-96 
Cornwell, W.K., Cornelissen, J.H.C., Amatangelo, K., Dorrepaal, E., Eviner, V.T., Godoy, O., et al. (2008). Plant species traits are the predominant control on litter decomposition rates within biomes worldwide. Ecol. Lett., 11, 1065-1071

Costantini, D., Edwards, D.P. \& Simons, M.J.P. (2016). Life after logging in tropical forests of Borneo: A meta-analysis. Biol. Conserv., 196, 182-188

Díaz, S., Kattge, J., Cornelissen, J.H.C., Wright, I.J., Lavorel, S., Dray, S., et al. (2016). The global spectrum of plant form and function. Nature, 529, 167-171

Dent, D.H. \& Burslem, D.F.R.P. (2016). Leaf traits of dipterocarp species with contrasting distributions across a gradient of nutrient and light availability. Plant Ecol. Divers., 9, 1-13

De Deyn, G.B., Cornellissen, J.H.C. \& Bardgett, R.D. (2008). Plant functional traits and soil carbon sequestration in contrasting biomes. Ecol. Lett., 11, 516-531

Edwards, F.A., Edwards, D.P., Larsen, T.H., Hsu, W.W., Benedick, S., Chung, A., et al. (2014). Does logging and forest conversion to oil palm agriculture alter functional diversity in a biodiversity hotspot? Anim. Conserv., 17, 163-173

Essene, A.L., Shek, K.L., Lewis, J.D., Peay, K., McGuire, K.L. 2017. Soil type has a stronger role than dipterocarp host species in shaping the ectomycorrhizal fungal community in a Bornean lowland tropical rain forest. Frontiers in Plant Science 8:1828.

Ewers, R.M., Didham, R.K., Fahrig, L., Ferraz, G., Hector, A., Holt, R.D., et al. (2011). A large-scale forest fragmentation experiment: the Stability of Altered Forest Ecosystems Project. Philos. Trans. R. Soc. B Biol. Sci., 366, 3292-3302

Farquhar, G.D., Ehleringer, J.R. \& Hubick, K.T. (1989). Carbon Isotope Discrimination and Photosynthesis. Annu. Rev. Plant Physiol. Plant Mol. Biol., 40, 503-537

Finegan, B., Pena-Claros, M., de Oliveira, A., Ascarrunz, N., Bret-Harte, M.S., Carreño-Rocabado, G., et al. (2015). Does functional trait diversity predict above-ground biomass and productivity of tropical forests? Testing three alternative hypotheses. J. Ecol., 103, 191-201

Fisher, B., Edwards, D.P., Giam, X. \& Wilcove, D.S. (2011). The high costs of conserving Southeast Asia's lowland rainforests. Front. Ecol. Environ., 9, 329-334

Fortunel, C., Garnier, E. \& Joffre, R. (2009). Leaf traits capture the effects of land use changes and climate on litter decomposability of grasslands across Europe. Ecology, 90, 598-611

Fortunel, C., Paine, C.E.T., Fine, P.V.A., Kraft, N.J.B. \& Baraloto, C. (2014a). Environmental factors predict community functional composition in Amazonian forests. J. Ecol., 102, 145-155

Fortunel, C., Ruelle, J., Beauchêne, J., Fine, P.V.A. \& Baraloto, C. (2014b). Wood specific gravity and anatomy of branches and roots in 113 Amazonian rainforest tree species across environmental gradients. New Phytol., 202, 79-94 
Fyllas, N.M., Patiño, S., Baker, T.R., Nardoto, G.B., Martinelli, L.A., Quesada, C.A., et al. (2009). Basinwide variations in foliar properties of Amazonian forest: phylogeny, soils and climate. Biogeosciences, 6, 2677-2708

Fyllas, N.M., Bentley, L.P., Shenkin, A., Asner, G.P., Atkin, O.K., Farfan-Rios, W., et al. (2017). Solar radiation and functional traits explain the decline of forest primary productivity along a tropical elevation gradient. Ecol. Lett., 20, 730-740

García, L. V. 2004. Escaping the Bonferroni iron claw in ecological studies. Oikos 105:657-663.

Gaveau, D.L.A., Sloan, S., Molidena, E., Yaen, H., Sheil, D., Abram, N.K., et al. (2014). Four Decades of Forest Persistence, Clearance and Logging on Borneo. PLoS One, 9, 1-11

Gibson, L., Lee, T.M., Koh, L.P., Brook, B.W., Gardner, T. a., Barlow, J., et al. (2011). Primary forests are irreplaceable for sustaining tropical biodiversity. Nature, 478, 378-381

Gómez-González, S., Torres-Díaz, C., Bustos-Schindler, C. \& Gianoli, E. (2011). Anthropogenic fire drives the evolution of seed traits. Proc. Natl. Acad. Sci., 108, 18743-18747

Hansen, M.C.C., Potapov, P. V, Moore, R., Hancher, M., Turubanova, S.A., Tyukavina, A., et al. (2013). High-Resolution Global Maps of 21st-Century Forest Cover Change. Science, 342, 850-854

Hardwick, S.R., Toumi, R., Pfeifer, M., Turner, E.C., Nilus, R. \& Ewers, R.M. (2015). The relationship between leaf area index and microclimate in tropical forest and oil palm plantation: Forest disturbance drives changes in microclimate. Agric. For. Meteorol., 201, 187-195

IPCC, 2013. Climate Change 2013 - The Physical Science Basis. In: Stocker, T.F., Qin, D., Plattner, G.-K., Tignor, M., Allen, S.K., Nauels, J.A., Xia, Y., Bex, V., Midgley,

P.M. (Eds.), The Physical Science Basis. Contribution of Working Group I to the Fifth Assessment Report of the Intergovernmental Panel on Climate Change. Cambridge University Press, UK, Cambridge. doi: 10.1017/СВ09781107415324. Jager, M.M., Richardson, S.J., Bellingham, P.J., Clearwater, M.J. \& Laughlin, D.C. (2015). Soil fertility induces coordinated responses of multiple independent functional traits. J. Ecol., 103, 374-385

Laliberté, E. \& Legendre, P. (2010). A distance-based framework for measuring functional diversity from multiple traits. Ecology, 91, 299-305

Laliberté, E., Lambers, H., Burgess, T.I. \& Wright, S.J. (2015). Phosphorus limitation, soil-borne pathogens and the coexistence of plant species in hyperdiverse forests and shrublands. New Phytol.,, 206(2), 507-521

Malhi, Y., Doughty, C.E., Goldsmith, G.R., Metcalfe, D.B., Girardin, C.A., Marthews, T.R. , et al. (2015). The linkages between photosynthesis, productivity, growth and biomass in lowland Amazonian forests. Glob Chang Biol, 21(6), 2283-2295 
Marsh, W. \& Greer, A.G. (1992). Forest land-use in Sabah, Malaysia: an introduction to Danum Valley Phil. Trans. R. Soc. Lond. B., 335, 331-339

Mayfield, M.M., Ackerly, D. \& Daily, G.C. (2006). The diversity and conservation of plant reproductive and dispersal functional traits in human-dominated tropical landscapes. J. Ecol., 94, 522-536

Mayfield, M.M., Bonser, S.P., Morgan, J.W., Aubin, I., McNamara, S. \& Vesk, P.A. (2010). What does species richness tell us about functional trait diversity? Predictions and evidence for responses of species and functional trait diversity to land-use change. Glob. Ecol. Biogeogr., 19, 423-431

McGuire, K.L., D'Angelo, H., Brearley, F.Q., Gedallovich, S.M., Babar, N., Yang, N., Gillikin, C.M., Gradoville, R., Bateman, C., Turner, B.L. and Mansor, P., 2015. Responses of soil fungi to logging and oil palm agriculture in Southeast Asian tropical forests. Microbial ecology, 69(4), pp.733-747.

Mclntyre, S., Lavorel, S., Landsberg, J. \& Forbes, T.D.A. (1999). Disturbance response in vegetation towards a global perspective on functional traits. J. Veg. Sci., 10, 621-630

Mouillot, D., Graham, N.A.J., Villéger, S., Mason, N.W.H. \& Bellwood, D.R. (2013a). A functional approach reveals community responses to disturbances. Trends Ecol. Evol., 28, 167-177

Mouillot, D., Bellwood, D.R., Baraloto, C., Chave, J., Galzin, R., Harmelin-Vivien, M., et al. (2013b). Rare Species Support Vulnerable Functions in High-Diversity Ecosystems. PLoS Biol 11(5), 1-11

Nainar, A., Bidin, K., Walsh, R.P., Ewers, R.M. \& Reynolds, G. (2015). Variations in suspended sediment yield and dynamics in catchments of differing land-use in Sabah. Transactions on Science and Technology, 2(1), 1-19

Newbery, D.M. \& Lingenfelder, M. (2009). Plurality of tree species responses to drought perturbation in Bornean tropical rain forest. Plant Ecol., 201, 147-167

Ordoñez, J.C., Bodegom, P.M. Van, Witte, J.M., Wright, I.J., Reich, P.B. \& Aerts, R. (2009). A global study of relationships between leaf traits, climate and soil measures of nutrient fertility. Glob. Ecol. Biogeogr., 18, 137-149

Osman, R., Phua, M., Ling, Z.Y. \& Kamlun, K.U. (2012). Monitoring of Deforestation Rate and Trend in Sabah between 1990 and 2008 Using Multitemporal Landsat Data. J. For. Sci., 28, 144-151

Paine, C.E.T., Baraloto, C. \& Díaz, S. (2015). Optimal strategies for sampling functional traits in speciesrich forests. Funct. Ecol., 29, 1325-1331

Pérez-Harguindeguy, N., Díaz, S., Garnier, E., Lavorel, S., Poorter, H., Jaureguiberry, P., et al. (2013). New Handbook for standardized measurement of plant functional traits worldwide. Aust. J. Bot., $61,167-234$

Pfeifer, M., Kor, L., Nilus, R., Turner, E., Cusack, J., Lysenko, I., et al. (2016). Mapping the structure of Borneo's tropical forests across a degradation gradient. Remote Sens. Environ., 176, 84-97 
Pinard, M.A., Barker, M.G., \& Tay, J. (2000). Soil disturbance and post-logging forest recovery on bulldozer paths in Sabah, Malaysia. For. Ecol. Manage., 130(1-3), 213-225

Pla, L., Casanoves, F. \& Di Rienzo, J. (2012). Functional diversity indices. In Quantifying Functional Biodiversity (pp. 27-51). Springer, Dordrecht, The Netherlands

Potapov, P., Hansen, M.C., Laestadius, L., Turubanova, S., Yaroshenko, A., Thies, C., et al. (2017). The last frontiers of wilderness: Tracking loss of intact forest landscapes from 2000 to 2013. Sci. Adv., 3, $1-13$

Quesada, C.A., Lloyd, J., Schwarz, M., Patiño, S., Baker, T.R., Czimczik, C.I., et al. (2010). Variations in chemical and physical properties of Amazon forest soils in relation to their genesis. Biogeosciences, 7, 1515-1541.

Quesada, C.A., Phillips, O.L., Schwarz, M., Czimczik, C.I., Baker, T.R., Patiño, S., et al. (2012). Basin-wide variations in Amazon forest structure and function are mediated by both soils and climate. Biogeosciences, 9, 2203-2246

R Core Team (2017). R: A language and environment for statistical computing. R Foundation for Statistical Computing, Vienna, Austria

Rao, R.C. (1982). Diversity and Dissimilarity Coefficients: A Unified Approach. Theor. Popul. Biol., 21, $24-43$

Reich, P. B., Wright, I. J., Cavender-Bares, J., Craine, J. M., Oleksyn, J., Westoby, M., et al. (2003). The evolution of plant functional variation: traits, spectra, and strategies. International Journal of Plant Sciences, 164(S3), S143-S164

Ricotta, C., \& Moretti, M. (2011). CWM and Rao's quadratic diversity: a unified framework for functional ecology. Oecologia, 167(1), 181-188

Riutta, T., Malhi, Y., Kho, L. K., Marthews, T. R., Huaraca Huasco, W., Khoo, M., et al. (2018). Logging disturbance shifts net primary productivity and its allocation in Bornean tropical forests. Glob Change Biol., 00, 1-16

Rumman, R., Atkin, O.K., Bloomfield, K.J. \& Eamus, D. (2018). Variation in bulk-leaf ${ }^{13} \mathrm{C}$ discrimination, leaf traits and water-use efficiency-trait relationships along a continental-scale climate gradient in Australia. Glob Change Biol., 24, 1186-1200

Rutishauser, E., Hérault, B., Baraloto, C., Blanc, L., Descroix, L., Sotta, E.D., Ferreira, J., Kanashiro, M., Mazzei, L., d'Oliveira, M.V. and De Oliveira, L.C., 2015. Rapid tree carbon stock recovery in managed Amazonian forests. Current Biology, 25(18), pp.R787-R788

Scriven, S.A., Hodgson, J.A., McClean, C.J. and Hill, J.K., 2015. Protected areas in Borneo may fail to conserve tropical forest biodiversity under climate change. Biological Conservation, 184, pp.414423. 
Stibig, H.J., Achard, F., Carboni, S., Rasi, R. \& Miettinen, J. (2014). Change in tropical forest cover of Southeast Asia from 1990 to 2010. Biogeosciences, 11, 247-258

Struebig, M.J., Turner, A., Giles, E., Lasmana, F., Tollington, S., Bernard, H., et al. (2013). Quantifying the Biodiversity Value of Repeatedly Logged Rainforests: Gradient and Comparative Approaches from Borneo. Adv. Ecol. Res. 1st edn. Elsevier Ltd.

Turnbull, M.H., Griffin, K.L., Fyllas, N.M., Lloyd, J., Meir, P. \& Atkin, O.K. (2016). Separating species and environmental determinants of leaf functional traits in temperate rainforest plants along a soildevelopment chronosequence. Funct. Plant Biol., 43, 751-765

Van der Sande, M.T., Arets, E.J.M.M., Pena-Claros, M., Luciana de Avila, A., Roopsind, A., Mazzei, L., et al. (2016). Old-growth Neotropical forests are shifting in species and trait composition. Ecol. Monogr., 86, 228-243

Verburg, R. \& van Eijk, C. (2003). Effects of selective logging on tree diversity, composition and plant functional type patterns in a Bornean rain forest. J. Veg. Sci., 14, 99

Walsh, R.P.D. \& Newbery, D.M. (1999). The ecoclimatology of Danum, Sabah, in the context of the world's rainforest regions, with particular reference to dry periods and their impact. Philos. Trans. R. Soc. B-Biological Sci., 354, 1869-1883

Wright, I.J., Westoby, M., Reich, P.B., Oleksyn, J., Ackerly, D.D., Baruch, Z., et al. (2004). The worldwide leaf economics spectrum. Nature, 428, 821-827 


\section{Figure captions}

Figure 1: Principal component analysis (PCA) of plot-level soil properties. The highest loadings on the first axis are CEC (12.6\%), total $\mathrm{Mg}(12.3 \%)$ and total $\mathrm{P}(12.2 \%)$. The highest loadings on the second axis are exchangeable $\mathrm{K}(12.0 \%)$, total $\mathrm{N}(11.1 \%)$ and exchangeable Ca (11.1\%). See Table S2 for all PCA loadings.

Figure 2: Principal component analysis (PCA) of plot-level community-weighted mean functional traits. Plots cluster by logging history, with increased values of traits that maximise carbon capture and growth in logged forest communities and greater allocation to tissue persistence and structural stability in old-growth forests. The highest loadings on the first axis are chlorophyll $b_{m}(4.44 \%), N_{a}$ (4.37\%), branch wood density (4.25\%), $\mathrm{A}_{\text {sat }}(4.25 \%), \mathrm{A}_{\max }(4.21 \%)$ and SLA (4.17\%). The highest loadings on second axis are $P_{m}(7.45 \%)$, LA (7.02\%), tannins (6.22\%), $C_{m}(5.88 \%)$ and leaf dry weight $(5.75 \%)$. Mass-based nutrients are denoted by superscript " $\mathrm{m}$ " and area-based values by superscript "a". See Table S3 for all PCA loadings.

Figure 3: Proportion of variance in community-weighted mean functional trait values explained by forest type and the first two principal components of soil properties (Fig. 1). Functional traits are grouped by the ecosystem function to which they most contribute. Statistical significance is derived from linear regression models following false discovery rate correction, asterisks indicate $p<0.05$, ' + ' and '-' indicate the direction of the relationship. For forest type ' + ' indicates that trait values were greater in selectively logged than old-growth forests (i.e. positive with first PC axis). For variance explained by soil, ' + ' indicates positive relationship with the respective PC axis. See Table 2 and Table S4 for detailed results.

Figure 4: Box-and-whisker plots showing the median, upper and lower quartile of functional diversity calculated as Rao's $Q$ with no significant difference between forest type (ANOVA: $F_{1,6}=0.16, p=0.70$ ). Tables 
671 Table 1: Study plot description and soil properties, plots are listed with decreasing basal area. Basal

672 area, stem density and number of tree species refers to all tree individuals $\geq 10 \mathrm{~cm} \mathrm{dbh}$.

\begin{tabular}{|c|c|c|c|c|c|c|c|c|c|c|c|c|c|c|c|c|c|c|}
\hline Plot name & Location & $\begin{array}{l}\text { Total basal } \\
\text { area }\left[\mathrm{m}^{2} \mathrm{ha}^{-1}\right]\end{array}$ & $\begin{array}{l}\text { Stem } \\
\text { density }\end{array}$ & $\begin{array}{l}\text { Number } \\
\text { of species }\end{array}$ & $\begin{array}{c}\mathrm{C} \\
{[\%]}\end{array}$ & $\begin{array}{c}\mathbf{N} \\
{[\%]}\end{array}$ & $\begin{array}{c}\text { Total P } \\
{\left[\mathrm{mg} \mathrm{kg}^{-1}\right]}\end{array}$ & $\begin{array}{l}\text { Total Ca } \\
{\left[\mathrm{mg} \mathrm{kg}^{-1}\right]}\end{array}$ & $\begin{array}{r}\text { Total K } \\
{\left[\mathrm{mg} \mathrm{kg}{ }^{-1}\right]} \\
\end{array}$ & $\begin{array}{l}\text { Total } \mathrm{Mg} \\
{\left[\mathrm{mg} \mathrm{kg}^{-1}\right]}\end{array}$ & $\begin{array}{c}\text { eCEC } \\
{\left[\mathrm{mmol}^{\mid} \mathrm{kg}^{-1}\right]}\end{array}$ & $\begin{array}{c}\mathrm{pH} \\
\left(\mathrm{H}_{2} \mathrm{O}\right)\end{array}$ & $\begin{array}{c}\mathrm{NO}_{3} \\
{\left[\mu \mathrm{g} 10 \mathrm{~cm}^{2} 14 \text { days }^{-1}\right]}\end{array}$ & $\begin{array}{c}\mathrm{NH}_{4}^{+} \\
\left.{ }^{-1}\right]\left[\mu \mathrm{g} 10 \mathrm{~cm}^{2} 14 \text { days }\right. \\
\end{array}$ & $\begin{array}{c}\text { Exchangable Ca } \\
{\left[\text { [ug } 10 \mathrm{~cm}^{2} 14 \text { days }{ }^{-11}\right.}\end{array}$ & $\begin{array}{c}\text { Exchangable } \mathrm{Mg} \\
{\left[\text { [ug } 10 \mathrm{~cm}^{2} 14 \text { days }{ }^{-1}\right]}\end{array}$ & $\begin{array}{c}\text { Exchangable } K \\
{\left[\mu \mathrm{B} 10 \mathrm{~cm}^{2} 14 \text { days }^{-1}\right]}\end{array}$ & 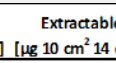 \\
\hline \multicolumn{19}{|c|}{ Old-growth forest (OG) } \\
\hline MLA-01 & MBCA & 41.8 & 396 & 141 & 1.67 & 0.14 & 163.01 & 50.06 & 101.03 & 39.67 & 36.44 & 3.95 & $59.6 \pm 45.2$ & $10.5 \pm 3.11$ & $237 \pm 130$ & $152 \pm 80.6$ & $265 \pm 154$ & $0.23 \pm$ \\
\hline MLA-02 & MBCA & 37.3 & 484 & 170 & 2.00 & 0.17 & 266.44 & 194.68 & 80.62 & 99.41 & 43.18 & 4.25 & $184 \pm 103$ & $6.37 \pm 1.52$ & $417 \pm 476$ & $303 \pm 215$ & $151 \pm 80.2$ & $0.433 \pm$ \\
\hline DAN-04 & DVCA & 30.8 & 456 & 128 & 1.80 & 0.18 & 557.21 & 603.28 & 16.12 & 389.63 & 63.88 & 5.81 & $75.2 \pm 57.2$ & $11.9 \pm 12.7$ & $480 \pm 596$ & $235 \pm 187$ & $268 \pm 158$ & $0.177 \pm$ \\
\hline DAN-05 & DVCA & 29.1 & 413 & 144 & 1.84 & 0.17 & 255.59 & 140.50 & 77.03 & 180.37 & 44.90 & 4.46 & $154 \pm 164$ & $5 \pm 1.88$ & $737 \pm 682$ & $271 \pm 183$ & $305 \pm 269$ & $1.03 \pm$ \\
\hline \multicolumn{19}{|c|}{ Selectively logged forest (SL) } \\
\hline SAF-03 & SAFE project & 25.8 & 565 & 211 & 1.89 & 0.16 & 231.05 & 40.42 & 115.55 & 38.65 & 35.66 & 3.68 & $83.8 \pm 63.7$ & $26.4 \pm 44.9$ & $392 \pm 265$ & $318 \pm 201$ & $332 \pm 308$ & $8.51 \pm$ \\
\hline SAF-04 & SAFE project & 19.5 & 465 & 188 & 7.15 & 0.32 & 117.07 & 107.71 & 67.21 & 41.36 & 14.55 & 3.90 & $83.4 \pm 60.5$ & $2.68 \pm 4.32$ & $1.35 * 10^{3} \pm 621$ & $310 \pm 94.1$ & $45.1 \pm 58$ & $1.18 \pm$ \\
\hline SAF-02 & SAFE project & 14.8 & 416 & 124 & 1.51 & 0.12 & 137.33 & 160.50 & 105.86 & 41.80 & 49.38 & 4.04 & $340 \pm 239$ & $23.9 \pm 33.2$ & $182 \pm 187$ & $191 \pm 173$ & $401 \pm 239$ & $0.464 \pm$ \\
\hline SAF-01 & SAFE project & 10.9 & 331 & 129 & 3.08 & 0.28 & 375.15 & 887.03 & 96.37 & 266.36 & 70.76 & 4.66 & $20 \pm 17.5$ & $16.8 \pm 18.7$ & $212 \pm 269$ & $79 \pm 67.6$ & $245 \pm 90.6$ & $3.03 \pm$ \\
\hline
\end{tabular}


$675 S L$ - selectively logged), and continuous 'soil PC1' and 'soil PC2'. For analyses values of dark respiration $R_{d}$ fluxes and $\delta^{13} C$ were converted to positive values 


\begin{tabular}{|c|c|c|c|c|c|c|c|c|}
\hline \multirow[b]{2}{*}{ Functional trait } & \multicolumn{2}{|c|}{ CWM trait value (95\% confindence intervals) } & \multicolumn{2}{|c|}{ Forest type } & \multicolumn{2}{|r|}{ Soil PC1 } & \multicolumn{2}{|r|}{ Soil PC2 } \\
\hline & OG & SL & F value & p-value & F value & $p$-value & $F$ value & $\mathrm{p}$-value \\
\hline hemicellulose_perc & $12.3(11.4-13.1)$ & $11.8(11-12.6)$ & 1.7284 & $0.4371 \mathrm{~ns}$ & 0.7672 & $0.5839 \mathrm{~ns}$ & 0.27 & $0.725 \mathrm{~ns}$ \\
\hline cellulose_perc & $22.5(20.9-24)$ & $20.9(19.4-22.4)$ & 3.3431 & $0.3055 \mathrm{~ns}$ & 0.3132 & $0.725 \mathrm{~ns}$ & 0.995 & $0.538 \mathrm{~ns}$ \\
\hline lignin_recalcitrants_perc & $19.4(17.3-21.4)$ & $17.3(15.3-19.2)$ & 2.7065 & $0.3403 \mathrm{~ns}$ & 3.333 & $0.3055 \mathrm{~ns}$ & 0.0803 & $0.8265 \mathrm{~ns}$ \\
\hline Total_tannin_mg_gDW & $8.56(7.7-9.41)$ & $9.41(8.6-10.2)$ & 8.8879 & $0.1586 \mathrm{~ns}$ & 8.0687 & $0.1626 \mathrm{~ns}$ & 0.0043 & $0.9508 \mathrm{~ns}$ \\
\hline Total_phenol_mg_gDW & $36.4(33.7-39.1)$ & $42.7(40.2-45.3)$ & 29.9599 & $0.0641 \mathrm{~ns}$ & 5.0043 & $0.2147 \mathrm{~ns}$ & 2.762 & $0.3403 \mathrm{~ns}$ \\
\hline WD_B & $0.564(0.528-0.599)$ & $0.493(0.46-0.526)$ & 15.3085 & $0.1227 \mathrm{~ns}$ & 2.4421 & $0.3608 \mathrm{~ns}$ & 1.5223 & $0.4406 \mathrm{~ns}$ \\
\hline LDMC_mg_g_mean & $416(391-440)$ & $410(387-433)$ & 0.1426 & $0.78 \mathrm{~ns}$ & 0.3322 & $0.725 \mathrm{~ns}$ & 0.0786 & $0.8265 \mathrm{~ns}$ \\
\hline Fp_N_mm_mean & $0.266(0.227-0.311)$ & $0.212(0.183-0.247)$ & 7.611 & $0.1626 \mathrm{~ns}$ & 0.2997 & $0.725 \mathrm{~ns}$ & 0.2597 & $0.725 \mathrm{~ns}$ \\
\hline specific_Fp_mean & $1.23(1.03-1.47)$ & $0.889(0.751-1.05)$ & 13.209 & $0.1285 \mathrm{~ns}$ & 0.4308 & $0.686 \mathrm{~ns}$ & 0.013 & $0.9337 \mathrm{~ns}$ \\
\hline leaf_thickness_mm_mean & $0.221(0.209-0.233)$ & $0.236(0.224-0.249)$ & 7.1956 & $0.1697 \mathrm{~ns}$ & 0.2132 & $0.7434 \mathrm{~ns}$ & 2.3189 & $0.3712 \mathrm{~ns}$ \\
\hline dry_weight_mg_mean & $922(784-1.08 \mathrm{e}+03)$ & $1.08 \mathrm{e}+03(930-1.27 \mathrm{e}+03)$ & 2.0771 & $0.4013 \mathrm{~ns}$ & 10.6002 & 0.1385 ns & 6.1195 & $0.1891 \mathrm{~ns}$ \\
\hline LA_mm2_mean & $1.37 e+04(1.13 e+04-1.65 e+04)$ & $1.31 e+04(1.1 e+04-1.57 e+04)$ & 1.6779 & $0.4371 \mathrm{~ns}$ & 11.1158 & $0.1367 \mathrm{~ns}$ & 1.8983 & $0.4249 \mathrm{~ns}$ \\
\hline SLA_mm2_mg_mean & $16.3(15.3-17.4)$ & $13.2(12.2-14.1)$ & 52.0691 & $0.057 \mathrm{~ns}$ & 3.0363 & 0.3225 ns & 5.338 & $0.2081 \mathrm{~ns}$ \\
\hline chla_mg.g & $2.62(2.54-2.71)$ & $2.49(2.41-2.57)$ & 13.8526 & $0.1285 \mathrm{~ns}$ & 0.967 & $0.539 \mathrm{~ns}$ & 0.0201 & $0.922 \mathrm{~ns}$ \\
\hline chla_mg.mm2 & $0.00018(0.000169-0.000192)$ & $0.000206(0.000195-0.000217)$ & 29.1407 & $0.0641 \mathrm{~ns}$ & 1.4573 & $0.4408 \mathrm{~ns}$ & 7.0602 & $0.1697 \mathrm{~ns}$ \\
\hline chlb_mg.g & $1.09(1.05-1.13)$ & $0.97(0.931-1.01)$ & 40.3793 & $0.0622 \mathrm{~ns}$ & 0.0054 & 0.9508 ns & 2.6047 & $0.3462 \mathrm{~ns}$ \\
\hline chlb_mg.mm2 & $7.42 \mathrm{e}-05(6.79 \mathrm{e}-05-8.04 \mathrm{e}-05)$ & $7.95 e-05(7.36 e-05-8.55 e-05)$ & 5.5521 & $0.2032 \mathrm{~ns}$ & 1.6784 & 0.4371 ns & 1.3329 & $0.4618 \mathrm{~ns}$ \\
\hline carot_mg.g & $0.687(0.667-0.708)$ & $0.667(0.647-0.687)$ & 6.3526 & $0.1891 \mathrm{~ns}$ & 1.5548 & $0.4406 \mathrm{~ns}$ & 0.2638 & $0.725 \mathrm{~ns}$ \\
\hline carot_mg.mm2 & $4.74 e-05(4.47 e-05-5.02 e-05)$ & $5.54 \mathrm{e}-05(5.28 \mathrm{e}-05-5.79 \mathrm{e}-05)$ & 47.7257 & $0.057 \mathrm{~ns}$ & 1.7074 & 0.4371 ns & 7.9565 & $0.1626 \mathrm{~ns}$ \\
\hline Asat_mean & $4.08(2.66-5.5)$ & $7.03(5.69-8.38)$ & 20.2667 & $0.0936 \mathrm{~ns}$ & 0.2841 & 0.725 ns & 4.4952 & $0.2333 \mathrm{~ns}$ \\
\hline Amax_mean & $11.7(8.94-14.5)$ & $18(15.4-20.6)$ & 23.2366 & $0.0844 \mathrm{~ns}$ & 0.8777 & $0.5526 \mathrm{~ns}$ & 4.2675 & $0.2424 \mathrm{~ns}$ \\
\hline DR_mean & $1.03(0.871-1.19)$ & $1.25(1.09-1.4)$ & 7.7079 & $0.1626 \mathrm{~ns}$ & 1.546 & $0.4406 \mathrm{~ns}$ & 5.7587 & $0.199 \mathrm{~ns}$ \\
\hline N_mg.mm2 & $0.128(0.12-0.136)$ & $0.166(0.158-0.174)$ & 97.6994 & $0.0343 *$ & 0.5198 & $0.6654 \mathrm{~ns}$ & 19.7036 & $0.0936 \mathrm{~ns}$ \\
\hline total_P_mg.mm2 & $6.62 \mathrm{e}-05(6.21 \mathrm{e}-05-7.06 \mathrm{e}-05)$ & $8.04 \mathrm{e}-05(7.57 \mathrm{e}-05-8.54 \mathrm{e}-05)$ & 33.2076 & $0.0641 \mathrm{~ns}$ & 12.2667 & $0.1294 \mathrm{~ns}$ & 10.3913 & $0.1385 \mathrm{~ns}$ \\
\hline $\mathrm{X} 13 \mathrm{C}$ & $32.4(32.1-32.8)$ & $31.4(31.1-31.8)$ & 28.7751 & $0.0641 \mathrm{~ns}$ & 8.7471 & $0.1586 \mathrm{~ns}$ & 11.3558 & $0.1367 \mathrm{~ns}$ \\
\hline C_perc & $44.6(44.3-44.9)$ & $44.7(44.4-45)$ & 12.2663 & $0.1294 \mathrm{~ns}$ & 89.7169 & $0.0343 *$ & 0.2403 & $0.7309 \mathrm{~ns}$ \\
\hline total_P_mg.g & $0.998(0.912-1.09)$ & $0.99(0.909-1.08)$ & 1.4839 & $0.4408 \mathrm{~ns}$ & 13.2189 & $0.1285 \mathrm{~ns}$ & 0.444 & $0.686 \mathrm{~ns}$ \\
\hline N_perc & $1.83(1.74-1.91)$ & $1.97(1.89-2.05)$ & 9.1914 & $0.1586 \mathrm{~ns}$ & 7.7457 & $0.1626 \mathrm{~ns}$ & 4.523 & $0.2333 \mathrm{~ns}$ \\
\hline total_K_mg.g & $9.99(8.4-11.9)$ & $10.8(9.13-12.7)$ & 0.9229 & $0.5454 \mathrm{~ns}$ & 0.3208 & $0.725 \mathrm{~ns}$ & 2.7576 & $0.3403 \mathrm{~ns}$ \\
\hline total_Mg_mg.g & $2.57(2.06-3.2)$ & $2.41(1.96-2.97)$ & 0.7237 & $0.5925 \mathrm{~ns}$ & 1.2751 & 0.4687 ns & 0.4897 & $0.672 \mathrm{~ns}$ \\
\hline total_Ca_mg.g & $7.09(6.12-8.2)$ & $6.6(5.75-7.59)$ & 6.1143 & $0.1891 \mathrm{~ns}$ & 17.5554 & $0.1051 \mathrm{~ns}$ & 1.5777 & $0.4406 \mathrm{~ns}$ \\
\hline $\mathrm{X} 15 \mathrm{~N}$ & $1.64(0.966-2.32)$ & $0.846(0.204-1.49)$ & 5.032 & $0.2147 \mathrm{~ns}$ & 0.1854 & $0.7495 \mathrm{~ns}$ & 0.5269 & $0.6654 \mathrm{~ns}$ \\
\hline RaoQ & $0.791(0.735-0.847)$ & $0.789(0.736-0.842)$ & 0.1971 & $0.748 \mathrm{~ns}$ & 0.1187 & $0.7961 \mathrm{~ns}$ & 3.0601 & $0.3225 \mathrm{~ns}$ \\
\hline
\end{tabular}


Source of variation

$\square$ Forest type $\square$ Soil PC1 $\square$ Soil PC2 $\square$ Unexplained

Rao's Q +-

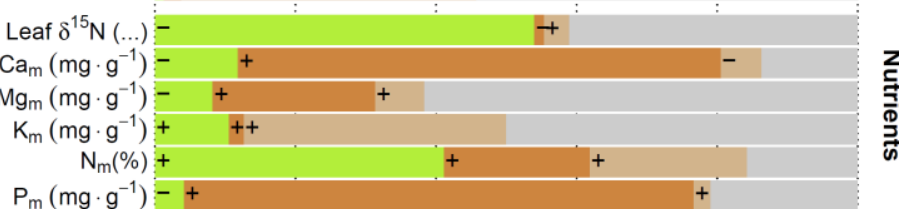

$+$

Leaf $\delta^{13} \mathrm{C}(\ldots)$

$\mathrm{P}_{\mathrm{a}}\left(\mathrm{mg} \cdot \mathrm{mm}^{-2}\right)+$

$\mathrm{Na}_{\mathrm{a}}\left(\mathrm{mg} \cdot \mathrm{mm}^{-2}\right)+*$

$R_{\mathrm{d}}\left(\mu \mathrm{mol} \cdot \mathrm{m}^{-2} \cdot \mathrm{s}^{-1}\right)+$

$A_{\max }\left(\mu \mathrm{mol} \cdot \mathrm{m}^{-2} \cdot \mathrm{s}^{-1}\right)+$

$A_{\text {sat }}\left(\mu \mathrm{mol} \cdot \mathrm{m}^{-2} \cdot \mathrm{s}^{-1}\right)$

Carotenoids $\mathrm{s}_{\mathrm{a}}\left(\mathrm{mg} \cdot \mathrm{mm}^{-2}\right)$

Carotenoids $\mathrm{m}\left(\mathrm{mg} \cdot \mathrm{g}^{-1}\right)$

Chlorophyll $\mathrm{b}_{\mathrm{a}}\left(\mathrm{mg} \cdot \mathrm{mm}^{-2}\right)+$

Chlorophyll $\mathrm{b}_{\mathrm{m}}\left(\mathrm{mg} \cdot \mathrm{g}^{-1}\right)$

Chlorophyll $\mathrm{a}_{\mathrm{m}}\left(\mathrm{mg} \cdot \mathrm{g}^{-1}\right)$

Specific leaf area $\left(\mathrm{mm}^{2} \cdot \mathrm{mg}^{-1}\right)$ -

Leaf area $\left(\mathrm{mm}^{2}\right)$ :-

Dry leaf mass $(\mathrm{mg})$

Lamina thickness $(\mathrm{mm})$

Specific force to punch $\left(\mathrm{N} \cdot \mathrm{mm}^{-2} \cdot \mathrm{mm}^{-1}\right)$

Force to punch $\left(\mathrm{N} \cdot \mathrm{mm}^{-2}\right)$ -

Leaf dry matter content $\left(\mathrm{mg} \cdot \mathrm{g}^{-1}\right)$ -

Branch density $\left(\mathrm{g} \cdot \mathrm{cm}^{-3}\right)$

Phenols $\mathrm{m}\left(\mathrm{mg} \cdot \mathrm{g}^{-1}\right)$

$\operatorname{Tannins}_{\mathrm{m}}\left(\mathrm{mg} \cdot \mathrm{g}^{-1}\right)+$

Lignin \& recalcitrants $(\%)$

Cellulose (\%) -

Hemicellulose (\%) -

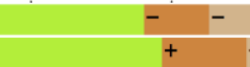

$+$

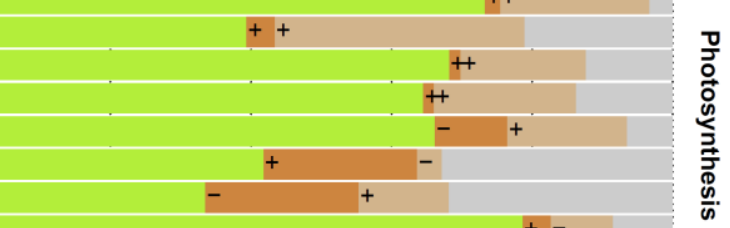

